$\begin{array}{llr}\text { KULTURA } & \begin{array}{l}\text { POLSKA AKADEMIA NAUK } \\ \text { KOMITET SOCJOLOGI }\end{array} & \begin{array}{r}\text { ISSN 0023-5172 } \\ 2300-195 \mathrm{x}\end{array} \\ \mathbf{\text { I }} & \begin{array}{l}\text { INSTYTUT STUDIÓW POLITYCZNYCH } \\ \text { SPOLECZENSTHO }\end{array} & \\ 2019, \text { nr } 4 \text { POLES IN THE WORLD OF LATE CAPITALISM }\end{array}$
$\begin{array}{llllllll}\text { A } & \mathbf{R} & \mathbf{T} & \mathrm{I} & \mathbf{C} & \mathrm{L} & \mathrm{E} & \mathrm{S}\end{array}$
A N D

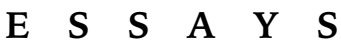

KAMILA BIAŁY, MARCIN GOŃDA, ANDRZEJ PIOTROWSKI

Institute of Sociology, University of Lodz

KAROL HARATYK

Institute of Sociology, University of Warsaw

ANNA ROSIŃSKA

Ca' Foscari University Venice \& University of Massachusetts Lowell

\title{
POLES IN THE WORLD OF LATE CAPITALISM: BIOGRAPHICAL EXPERIENCES IN CONTEXTS OF SOCIAL ORDERS*
}

\section{INTRODUCTORY REMARKS}

Poland's systemic transformation after 1989 has been imitative of solutions found in democratic and market-oriented social arrangements adopted by the contemporary Western societies. Contemporary Poles find themselves in the situation framed by simultaneous coexistence, hybrid-

Correspondence addresses:

email: kamila.bialy@uni.lodz.pl; ORCID: 0000-0003-4933-3570

email: marcin.gonda@uni.lodz.pl; ORCID: 0000-0003-0940-8849

email: andrzej.piotrowski@uni.lodz.pl; ORCID: 0000-0002-4161-1006

email: karolharatyk@gmail.com

email: anna.rosinska@unive.it; ORCID: 0000-0003-4508-5565 (Anna Rosińska published earlier as Anna Rosińska-Kordasiewicz and Anna Kordasiewicz)

* The paper is an outline of the research project Poles in the World of Late Capitalism: Changes of Biographical Processes in Terms of Professional Careers, Social Relations and Identity at the Time of System Transformation in Poland. The project was carried out in the Institute of Sociology, University of Lodz, in 2014-2018, and was financed by the Polish National Science Centre (NCN) within the OPUS scheme (grant no.: UMO-2013/11/B/HS6/01473).

Members of the research team were as follows: Andrzej Piotrowski (head), Kamila Biały, Marcin Gońda, Karol Haratyk and Anna Rosińska. 
isation and then collision of elements belonging to three social orders understood in terms of the principles that bind institutional solutions with spheres of cognitive, axiological and emotional orientations present in the post-socialist Poland: premodernity, modernity and postmodernity (Haratyk, Biały, Gońda 2017; Haratyk, Biały 2018; Kordasiewicz 2016). The first of these varieties within the Polish context is defined by certain elements of the heritage of earlier times, including, on the one hand, the heritage of the state socialism and, on the other hand, elements of the pre-modern culture, affecting the contemporary Polish reality in terms of long duration (cf. Braudel 1958). The second of these varieties are the social order arrangements adopted by Western societies of the modern era, that is, the classic liberal, democratic and market-oriented solutions. These solutions acted as an important framework of reference not only for the various concepts and projects of Poland's return to normality and the rational social order after the collapse of the state socialism, but also for the institutional devices promoting entrepreneurship in individuals (cf. Ziółkowski 1997).The third of these varieties is most often described in terms of postmodernity (also in terms of late or second modernity, or late capitalism) and the related processes of Europeanisation, globalisation, multiculturalism and transculturalism as well as the neoliberal economic order (cf. Giddens 1991; Beck 1992; Sennett 1998).

How do these three different types of social orders affect the process of navigating one's individual life in terms of work, social bounds and identity? And at the same time, what is the result of collision of these various logics and the need to solve dilemmas at the level of individual existence seen from the bottom-up perspective? Searching for answers to these questions was the aim of the project presented in this volume. It has been focused on the reconstruction of variations and dynamics of the biographical experience of the Polish society during (and after) the political transformation in 1989 in the sphere of (1) employment and professional careers, (2) social relations in private and public spheres and (3) experiences related to the sense of individual identity as well as social and cultural identity.

The analysis of transformation processes from a biographical perspective should be considered original, including the examination of these three different (previously treated separately) spheres of life. Unlike typical approaches, where the spheres of work and social relations are subordinated to the sphere of identity, the project was based on the assumption that the sphere of work, particularly that regulated by corporate standards, is one 
of the central determinants of individual's functioning in the late-capitalist world. Therefore, it sought to answer how various principles and expectations regulating the work process affect the organisation of one's course of life in terms of social relations and identity. In addition, research on social processes in post-transformation Poland in general has not been oriented towards the relationship between macrostructural (formal and institutional) determinants and the micro-level seen from the interpretative perspective. Few qualitative studies described, for example, a narrow category of managers, but did not cover broadly understood occupational categories (cf. Kaźmierska, Piotrowski, Waniek 2012). Meanwhile, corporate labor standards are no longer characteristic for narrowly understood international corporations, but penetrate the entire institutional field. The corporate model of functioning also colonizes non-professional areas of life. And indeed, the presented project's findings indicate that on the level of biographical processes the tensions of contemporary times associated with changes in the labor market, social relations and identity appear particularly vivid in the corporate work organisation. Thus, the research covered a broad spectrum of people whose experiences are related to the requirements of working in a corporate environment.

\section{RESEARCH METHODOLOGY AND STUDY GROUP}

The methodological framework for the collection and analysis of research data within the project Poles in the late capitalism... was guided by the autobiographical narrative method developed by Fritz Schütze (2008). It provides access to tools for comprehensive reconstruction of processes related to shaping personal orientations in their social context. Developed at the beginning of the 1970s, the method derives from interpretative sociology that assumes reality is constructed by individuals themselves in their daily interactions (Apitzsch, Inowocki 2000). It emphasises, first of all, on the one hand the subjectivity of individuals involved in the different biographical processes developing in accordance with specific patterns oscillating between the attitude of care, taking control over the individual's own life and authentic involvement, and, on the other hand, the category of suffering, being in the power of external and impersonal social institutions. Secondly, Schütze's approach assumes three levels of analysis: studying specific speech acts, narration extracts and argumentative structures brings information about communicative practices specific to the field under investigation, which, in turn, reflect social relations connected with institutional changes. In our study we also referred to methods 
elaborated by Gabriele Rosenthal as well as methods used in Gestalt psychology (1995). Within Gestalt's perspective, dilemmas and tensions that emerge in the life of individuals are treated as opening gestalts or figures. Following the self-regulation rule, these figures then seek to be closed. Rosenthal's approach suggests, in analytical terms, moving on from reconstructing gestalts discovered on the level of narration (discourse) to reconstructing gestalts of the individual's life experience (individual histories).

In a typical autobiographical narrative interviews the informant is asked at the beginning to present either his or her whole life or a given topic of interest, in which he or she participated, in an ex tempore narrative. After this stage the interviewer asks questions referring to the narrative's fragments that were not detailed enough before. Finally, in the third stage the informants play the role of experts and theorists of themselves (Flick 2009) and are asked questions that aim at "theoretical accounts of what happened and at balancing the story, reducing the 'meaning' of the whole to its common denominator" (Hermanns 1995). In this project a researcher met with an interviewee twice (the material lasts in consequence from three to six hours); the first life-story narration, particularly its narrative schemes, was deconstructed at the second meeting when an interviewee was asked to tell his or her present life, which turns out to be less prone to self-presentation strategies. As to data analysis, this process was carried out according Schütze's approach: generalisations were made by constant examining and comparing substantive features of various narratives. In this sense, biographical approach enabled to deconstruct social phenomena from individual perspective, irrespective of the number of cases being reviewed. Data analysis required high-quality transcription of the verbal material so that researchers could differentiate communicative schemes of narratives (narration, description, argumentation) as well as pauses, hesitations or paralinguistic phenomena (laughter, crying, self-corrections etc.), which are regarded as significant markers of the dynamics of informant's self-perception (Schütze 2008). All biographical details that could lead to identification of narrator's real name were also thoroughly concealed.

The empirical database of the presented project included 80 autobiographical narrative interviews conducted in years 2014-2017 in the largest Polish cities with employees of corporations or people who have contact with corporate practices in their professional lives. These interviews were delivered by 56 interviewees but we decided to modify the approach of Fritz Schütze by supplementing the interviews with 24 nar- 
rators with a second meeting during which separate interviews were conducted that focused on the narrators' worldview, present situation and selected issues considered to be crucial after analysis of the first interview. That collection of biographical stories was also supplemented by two biographical interviews (acknowledged to be key ones from the point of view of the presented analysed issues) from the Euroidentities project's collection (financed under the EU's $7^{\text {th }}$ Framework Programme in 2008-2011). In total 82 interviews were analysed. The study covered three posttransformation generations (understood as cohorts in the demographic sense) that were analytically distinguished based on the time they entered the labor market. These were: (1) persons born in 1966-75 (entered the labor market in the 1990s-12 people), (2) persons born in 1976-85 (entered the labor market as Poland joined the European Union in 2004-32 persons) and (3) persons born in 1986 and later (entered the labor market in the context of the global financial crisis of 2007-12 persons). It is among those entering the labor market at the time of Poland's accession to the EU that social categories are found that, as it seems, are most closely related to the requirements of corporate governance and therefore this group of respondents was the largest. In order to contrast the experiences of Poles from the communist era and the aftermath of the transformation, we also conducted two interviews with people born earlier (at the beginning of the 1940s and 1960s, respectively). Among the narrators there were 31 men and 27 women from the four largest Polish cities: Warsaw, Krakow, Lodz and Wroclaw.

Since the structural features of modern work organisation mean that corporate standards of project-based work style are no longer characteristic just of international corporation in the narrow senses, but have infiltrated the entire institutional field (law, finance, medicine, IT, education, consulting, etc.), the study covered various professional categories, including managers and regular employees in large and small domestic and foreign companies (corporations), professionals (IT specialists, engineers, lawyers), entrepreneurs and freelancers. Interviewees were initially recruited using social networks of team members and then by further recommendations from our study's participants. We sought to bring together as diverse biographical experiences of late capitalism as possible in a relatively narrowly defined but internally diverse category of persons associated with the corporate regime. With such a selection of the respondent group we could answer a number of previously posed research questions. 


\section{THE CONCEPT OF ORDER-GENERATING DIMENSIONS*}

The central analytical framework developed within the project was the concept of order-generating dimensions that was presented elsewhere by Haratyk and Biały (2018). The authors reconstruct the basic units of ordering social reality (the determinants of social orders) in the historical developments of societies. Haratyk and Biały note that in premodernity, it is the individual's rootedness in a community that predates its actions and determines the nature of its activity. Identity is a consequence of both - the duty and its realisation by the individual. In modernity, associations in which individuals participate become a derivative of their activity, however no one can choose the character of his/her activity arbitrarily. The range of available possibilities is still so narrow, and the consequences of choices so extensive within an individual biography that it should be claimed that it is the identity of an individual that is a derivative of his or her activity rather than the other way round. In postmodernity, neither the bonds of an individual, nor his or her work seems to be necessary and obvious. Thus, as casual, variable, not permanent on their own, but maintained or suspended by an individual together with other individuals, they cannot provide any ontological security in the sense proposed by Giddens (1984) and cannot become the foundation of such individual's social world. In postmodernity, the only keystone of an individual's social world can be himself or herself-his/her identity. Identity is therefore becoming, or seems to be, the cause rather than the result of work and bonds, both for those whose biography abounds in choices, and for those who are crushed by the burden of destabilized necessity. Even if this does not manifest itself in the type of activity undertaken by an individual or in the nature of social circles he or she co-creates, choice finds expression in the style, in the way in which an individual does what he or she does and is wherever he or she. Haratyk and Biały summarise this part of their statement and use hyperbolic terms to underline that whereas in premodernity the world brought man to life in its image and likeness, in modernity man creates a world in which he/she lives, but not himself/herself, and in postmodernity there is no world as such-there are only fragments of it, from which an individual creates his or her own world as a side effect of self-creation.

As presented in a table below, the communal unity of the premodern world only in modern order is separated into clearly distinct dimensions

\footnotetext{
* This chapter is a shortened version of the chapter The concept of order-generating dimensions inculded in the paper delivered by Haratyk and Biały (2018).
} 
of work, bonds and identity. In the community world, however, these dimensions can be distinguished not only in the analytical sense. Although within a community individuals vary in terms of their responsibilities and the effectiveness of their execution, they originate from the community. However, while affiliation with the community is a priori-given and necessary, the activity is a result not only of existing obligations, but also of the way in which they are fulfilled by an individual, which to some extent also influences the former. It is the character of the community and the place of the individual within it that gives rise to its identity, which is the individual's orientation towards the community. Therefore, in pre-modernity, work is "from-the-community" in character, and identity"to-the-community". The dark side of premodernity is due to the fatalistic character of the community and the place of an individual within it (cf. Walzer 2006).

In modernity, in which old communities are subject to destabilisation and reorganisation, it is work that becomes the dominant dimension. However, the work, unlike the individual self (identity) and collective self (bonds), is by necessity secondary to the individual and therefore cannot fully define his or her bonds and identity. Hence the modus of categorical diversification and compartmentalisation of reality characteristic of modernity, which is manifested among others in the division into public and private sectors and a clear distinction between individual spheres and types of activity. Hence the modern division into paid professional work that determines an individual's social position and identity, as well as its social anchoring in associations based on the employment relationship and character of work, and into the private life of an individual based on intimate relationships, in which he or she takes on family and friendship roles, as well as non-professional domestic work.

Just as work as such cannot fully define modern social reality, similarly, professional work cannot fully define the dimension of work itself. In addition to professional work in the public sphere, distinguishable from non-professional work in the private sphere, there is also non-professional work done as a hobby, as path of cultural, "social", political activity or as charity. More, there are also categories of the non-working, i. e. those who, despite the multitude of possible characteristics, are defined primarily by the one that is absent from their biography-namely by work; they are the unemployed, pensioners, temporarily unable to continue paid work, or those who do not want to do so. Thus, in the case of those who work professionally in the public sphere, who work in the private sphere (e. g. homemakers) and those who are not in employment, it is the relation to 
work and its type that determines the nature of the bonds and identity of an individual to a greater extent than the latter are defined by the work.

Negative biographical effects of modernity, as in the case of premodernity, result from the very essence of this order. Modern compartmentalisation exposes an individual to Merton's (1966) intrapersonal conflicts of roles and psychoanalytical conflicts resulting from the separation of the public sphere represented in the area of personality in Freudian images by the Superego, and the private sphere represented by the Id, between which the Ego, deprived of autonomy, must mediate.

The conformative nature of work and the precarious status of an individual's identity associated with the modern uncertainty of status provide a context for consideration of the spread of phenomena such as depression, hysteria and later also narcissism. In his study on suicide, Emil Durkheim (1967[1897]) pointed out that these acts were not only the result of mental problems, just as Sigmund Freud demonstrated that diseases such as hysteria, depression, various forms of phobias and obsessions were linked to the socio-historical context of Austria-Hungary (Freud 2011[1929]). The aim of psychoanalysis was to achieve maturity, which was an epitome of the ability to form bonds and perform work while simultaneously repressing drives, which was controlled by fear of the Superego.

The contextual equivalence at the social level and the possibility at the biographical level are the key to understanding postmodernity. As old forms of social reality have become liquid, new opportunities seem to appear to the individual. At the same time, in a situation of constant changeability of forms of social reality (variety and the flowing of some forms into others), an individual, trying to make his or her reality more consistent or being forced to react to constantly changing conditions of his or her life, must constantly seek new opportunities. As a result of the above, as well as due to the keystone character of identity in postmodernity, the work becomes self-realizing at the biography level. An individual no longer treats his or her activity as a modern obligation-external to him or her, but no longer a transcendental sanction, as opposed to the premodern obligation. Such individual's work becomes a realisation of his or her internal aspirations, or the image of identity. Therefore, the work is self-realizing not only for those who construct and confirm their own identity through it. Also those whose biography seems to be a domain of necessity rather than opportunity, experience their work in terms of an opportunity to realize themselves, though in a negated form. The bonds constitute a private, individual, contextually reconstructed network, in which neither the community nor the organisation is the keystone (the center and con- 
dition of persistence, as well as the source of energy required for that purpose), but the individual itself. However, the dark side of postmodernity is not only the result of the possibility of opportunities to transform into a necessity, but also of the blurring of social order and divisions within social reality; the psychological image of individuals in such a social setting is to some extent a borderline phenomenon-a completely new type of personality disorder (Spagnuolo Lobb 2011).

Table 1

Order-generating dimensions (modalizing dimensions in bold text)

\begin{tabular}{|c|c|c|c|}
\hline Order & Bond & Work & Identity \\
\hline Premodern order & community & from-the-community & to-the-community \\
\hline Modern order & $\begin{array}{c}\text { associational in the } \\
\text { professional sphere } \\
\text { and intimate in the } \\
\text { private sphere }\end{array}$ & $\begin{array}{c}\text { professional in the } \\
\text { public sphere, } \\
\text { non-professional in } \\
\text { the domestic sphere } \\
\text { and public } \\
\text { non-professional }\end{array}$ & $\begin{array}{c}\text { positional } \\
\text { (prone to conflicts of } \\
\text { roles and } \\
\text { psychoanalytical } \\
\text { conflicts) }\end{array}$ \\
\hline Postmodern order & $\begin{array}{c}\text { individualistically } \\
\text { networked }\end{array}$ & $\begin{array}{c}\text { self-realizing } \\
\text { (in the affirmative or } \\
\text { negative form) }\end{array}$ & individualistic \\
\hline
\end{tabular}

The value of the order-generating dimensions concept presented by Haratyk and Biały lies primarily in its usefulness in detecting and describing social and biographical tensions. As in the case of Weber's ideal types (1978) or constructs such as the Goffman's total institution (1961) or orders as understood by Ossowski (1983), in the course of abductive reasoning in the research process we are aiming not at a nominalistic description of reality, but at reducing its complexity to such categories that allow us to understand it, regardless of whether we want to recognize the reality of their existence or merely their cognitive usefulness. Even if there are examples of societies that are clear manifestations of premodern or modern order, empirical reality is a separate analytical level. This is particularly evident in the case of contemporaneity, whose image is determined not by any single order, but by the interference of premodernity, modernity and postmodernity. However, each of these orders creates/describes a different comprehensive configuration of social reality. As a consequence, the co-occurrence of their manifestations generates tensions which an individual at the social level experiences as maladjustment and inadequacy in the situation of non-routine encounter with a manifestation of the non- 
-dominant order in a given area. Analogous tensions at the biographical level take the form of disturbances of biographical processes and remain not fully understood by an individual in the circumstances of their occurrence. In addition, the individual him/herself can react to the tensions of his or her contemporaneity by using elements of the nonspecific orders in his/her strategies of coping with a life immersed in heterogeneous order.

\section{WORK, SOCIAL RELATIONS AND IDENTITY}

While analysing the area of Poles's professional, biographical data gathered within the project has shown that the current career model is based on precarious adaptation to the requirements of the labour market. One's overall relationship with the profession and the company replaces the tendency for lifelong training and retraining. The culturally established patterns of permanent relevance of the obtained educational status are no longer valid and do not allow individuals to seek for employment stability. Corporate standards of competitiveness, creativity and efficiency make this unstable work environment a source of a sense of biographical risk. At the same time, however, in postmodern times the work gains a self-realisation character at the level of one's biography. The work has a self-realisation feature both for those who construct and confirm their own identity through work, as well as for those who cannot get employment that would suit their self-image and who reconstruct their biographies in the sphere of work in terms of the impossibility of self-realisation. On the other hand, the analyses also show there are many people who cannot get satisfaction with their work and thus give up this self-fulfillment mode and return to the world of values determined by the modern order experiences (see papers by Biały and by Gońda in this volume).

With regard to the sphere of social ties, the empirical material confirmed that corporate practices colonize non-professional areas of life. The narrators are very individualistic and non-relational about their subjectivity and agency. Only a few individuals strive to relational subjectivity. In turn, among people for whom social relations seemed to be of higher importance, a number of relational modes were distinguished, including 'modern families' (who separate the professional and personal worlds), relational deprivation (i.e. experiencing various relational deficits with either paradoxical interactive efficiency, deep engagement in relation or in the situation of absence of interaction proficiency), cold intimacy (maintaining association-like and concurrent character of relations by partners as resulting from the same professional priorities) and alternative relational 
forms (friendship as a typically postmodern relation, nonheterosexual families, polyamorous relations, urban neotribes) (see paper by Rosińska and Gońda in this volume).

The study of identity transformations was focused on determining how individuals cope with the tensions derived from traditional and modern expectations of "strong" connections between collective self-categorisation and individual identifications, and, on the other hand, post-modern orientations that tend to treat identity in terms of symbolic repertoires defining cultural competences in variable contexts of actions and enabling the implementation of contextually individualized identity projects. The analysis of narrative interviews has shown that in the postmodern times one's biography is essentially focused on an individual project of himself/herself. Neither one's social relations nor his/her work seem to be necessary anymore. Thus, as contingent variables they cannot provide him/her the ontological safety and cannot become the foundation of his/her social world. At the same time, a number of identity dilemmas and tensions have been identified through analysis of collected data. First, the heritage of the People's Republic of Poland in the area of shaping education and career patterns is still permanent. Nowadays one can observe a confrontation of models of family upbringing (oriented towards professional career built through stable achieving of subsequent levels of education) with the requirements of working in institutions framed by corporate-like standards. Second, individuals are faced with the need to choose between, on the one hand, autonomy and stability, and, on the other hand, dependence. Their constant search for autonomy results in fear of becoming too entangled in professional relationships but also in family relations. Sometimes, however, the search for autonomy is not only conducted to find stability in life but it also becomes an autotelic goal. This trajectory of too many engagements is in this optics a structural feature of the world. One way to get out of these entanglements is neostoic individualism and radical rejection of the corporate-like organisation of one's life. Third, a strong pragmatisation of one's life orientations was identified. Identity processes are determined by the requirement to adapt to the institutional framework of the Polish version of postmodern order. There is a strong "seduction" by the corporate world (especially among those with lower socio-cultural capital and who come from peripheries) which, however, over time leads to strong crises and disappointments. As a result, one develops an adaptive mode that is not so much oriented towards the previously well-maintained professional sphere but rather aimed at private goals (see paper by Haratyk, Bialy, Gońda 2017). 


\section{REFERENCES}

Apitzsch, Ursula, Lena Inowlocki. 2000. “Biographical analysis. A ‘German' school?” In: P. Chamberlane, J. Bornat, T. Wengraf (eds.). The Turn to Biographical Methods in Social Science. Comparative Issues and Examples. London-New York: Routledge: 53-70.

Bauman, Zygmunt. 2000. Liquid Modernity. Cambridge: Polity Press.

Beck, Ulrich. 1992. Risk Society: Towards a New Modernity. London: Sage.

Braudel, Fernand. 1958. "Histoire et sciences sociales: La longue durée." Annales. Histoire, Sciences Sociales no. 4/13: 725-753.

Durkheim, Émile. 1967 [1897]. Suicide. Étude de sociologie. Paris: Presses universitaires de France.

Flick, Uwe. 2009. An Introduction to Qualitative Research. London: Sage.

Freud, Sigmund. 2011 [1929]. Civilization and Its Discontents. London: Penguin.

Giddens, Anthony. 1991. Modernity and Self-identity: Self and Society in the Late Modern Age. Stanford, Calif: Stanford University Press.

Giddens, Anthony. 1984. The Constitution of Society: Outline of the Theory of Structuration. Berkeley: University of California Press.

Gergen, Kenneth J. 2009. The Saturated Self: Dilemmas of Identity in Contemporary Life. New York: Basic Books.

Goffman, Erving. 1961. Asylums: Essays on the Social Situation of Mental Patients and Other Inmates. Garden City, NY: Doubleday.

Haratyk, Karol, Kamila Biały. 2018. "Outline of the concept of order-generation dimensions: hypermodernity in Polish society of late capitalism." Kultura i Spoteczeństwo/Culture and Society no 4: 47-68.

Haratyk, Karol, Kamila Biały, Marcin Gońda. 2017. "Biographical meanings of work: the case of a Polish freelancer.” Przegląd Socjologii Jakościowej 13(4): 136-159. (www.przegladsocjologiijakosciowej.org).

Hermanns, Harry. 1995. "Narratives interview." In: U. Flick, E. V. Kardorff, H. Keupp, L. V. Rosenstiel, S. Wolff (eds.). Handbuch qualitative Sozialforschung. Munich: Psychologie Verlags Union: 182-185.

Jacyno, Małgorzata. 2007. Kultura indywidualizmu. Warszawa: Wydawnictwo Naukowe PWN. Kaźmierska, Kaja, Andrzej Piotrowski, Katarzyna Waniek. 2012. “Transnational work in the biographical experiences of traditional professions and corporate executives: Analysis of two cases." In: R. Miller, G. Day (ed.). The Evolution of European Identities: Biographical Approaches. New York: Palgrave Macmillan: 76-101.

Kordasiewicz, Anna. 2016. (U)stugi domowe. Przemiany relacji społecznych w platnej pracy domowej. Toruń: Wydawnictwo UMK.

Lasch, Christopher. 1979. The Culture of Narcissism: American Life in an Age of Diminishing Expectations. New York: Norton.

Merton, Robert K. 1966. Social Theory and Social Structure. New York: The Free Press; London: Collier-Macmillan.

Ossowski, Stanisław. 1983. O osobliwościach nauk społecznych. Państwowe Wydawnictwo Naukowe: Warszawa.

Parsons, Talcott. 1970. "Some problems of general theory in sociology." In: J. C. McKinney, E. A. Tiryakian (ed.). Theoretical Sociology. Perspectives and Developments. New York: Appleton-Century-Crofts. 
Rosenthal, Gabriele. 1995, Erlebte und erzählte Lebensgeschichte. Gestalt und Struktur biographischer Selbstbeschreibungen. Frankfurt am Main: Campus.

Schütze, Fritz. 2008. Biography Analysis on the Empirical Base of the Autobiographical Narratives: How to Analyse Autobiographical Narrative Interviews. Part I, INVITE-Biographical Counselling in Rehabilitative Vocational Training. Further Educational Curriculum. EU Leonardo da Vinci Programme (http://www.zsm.ovgu.de/zsm_media/Das+Zentrum/ Forschungsprojekte/INVITE/B2_1-p-140.pdf).

Sennett, Richard. 1998. The Corrosion of Character: The Personal Consequences of Work in the New Capitalism. New York: Norton.

Spagnuolo Lobb, Margherita. 2011. The Now-for-Next in Psychotherapy Gestalt Therapy Recounted in Post-Modern Society. Milan: Instituto di Gestalt.

Walzer, Michael. 2006. Just and Unjust Wars: A Moral Argument with Historical Illustrations. New York: Basic Books.

Weber, Max. 1978[1922]. Economy and Society [Wirtschaft und Gesellschaft. Grundriß der verstehenden Soziologie]. Berkeley: University of California Press.

Ziółkowski, Marek. 1997. O różnorodności teraźniejszości (Pomiędzy tradycją, spuścizna socjalizmu, nowoczesnością a ponowoczesnościa), „Kultura i Społeczeństwo”, no 4.

\section{Abstract}

The paper presents findings of a research project aimed at a reconstruction of the dynamics of biographical experiences of some of those categories of the Polish society's members whose educational and professional careers have been shaped by the systemic transformation after 1989. The text is an attempt to delineate analytical guidelines for grasping how some components of three types of social order, conceived in terms of premodernity, modernity and postmodernity, interpenetrating each other in the contemporary life of the society, impact its members' biographical experiences on the level of work, social ties and identity.

Keywords: premodernity, modernity, postmodernity, social order, systemic transformation, biography, Poland

\section{POLACY W ŚWIECIE PÓŹNEGO KAPITALIZMU: DOŚWIADCZENIA BIOGRAFICZNE A ŁADY SPOŁECZNE}

Kamila Biały, Marcin Gońda, Andrzej Piotrowski (Instytut Socjologii, Uniwersytet Łódzki), Karol Haratyk (Instytut Socjologii, Uniwersytet Warszawski), Anna Rosińska (Ca' Foscari University Venice \& University of Massachusetts Lowell)

\section{Abstrakt}

W artykule zaprezentowano wyniki projektu badawczego dotyczącego rekonstrukcji dynamiki biograficznych doświadczeń wybranych kategorii członków pol- 
skiego społeczeństwa ostatniego ćwierćwiecza, których kariery edukacyjne i zawodowe kształtowały się w okresie transformacji systemowej po 1989 r. Tekst jest próbą wytyczenia analitycznych kategorii służących ustaleniu, w jaki sposób niektóre elementy trzech rodzajów porządku społecznego przenikających się we współczesnym życiu społeczeństwa (ujmowane tu w kategoriach przednowoczesności, nowoczesności i ponowoczesności) wpływają na doświadczenia biograficzne jego członków w obszarze pracy, więzi społecznych i tożsamości.

Słowa kluczowe: przednowoczesność, nowoczesność, ponowoczesność, ład społeczny, transformacja systemowa, biografia, Polska 